\title{
Trauma Course for an Aerial Medical Transport System in the Amazon Rainforest of Ecuador
}

Michel B Aboutanos, Francisco E Mora, Benjamin Nicholson, Jay Lovelady, Harrinder Dhindsa, Lina V Mata, Debbie Kleiman, Theresa Chin, Ashley King, Rao R Ivatury

\begin{abstract}
Objectives: Aerial transport of injured patients in rural Southeastern Ecuador is provided by humanitarian organizations with no medical personnel or assistance. We sought to evaluate the feasibility and usefulness of a tailored aeromedical transport (AMT) course for nonmedical personnel (pilot and technicians) in the jungles of Ecuador, where there are no formal medical crew members.
\end{abstract}

Methods: Fixed-wing aeromedical flights in the Amazon province of Morona Santiago were analyzed to delineate the injury patterns (IP) and reason for transport (RFT). An 8-hour didactic and hands-on AMTC course based on IP and RFT was developed and administered by the Virginia Commonwealth University (VCU) International trauma system development program (ITSDP) and VCU Life Evac with extensive experience in aeromedical education and training. Pre- and post-test course evaluation was used to assess the medical background and knowledge retention of the participants.

Results: A total of 5,716 fixed-wing aeromedical transports between Jan 2003 and Dec 2005 were analyzed. The course was developed based on 1176 (20\%) RFT resulting from traumatic injuries. Course structure based on identified IP included 4 didactic lectures and hands-on skill training in aerial physiology, airway management, bleeding control, shock, musculoskeletal injuries, immobilization and patient transport. Fifteen students (4 pilots, 4 engineers, 2 physicians, 4 aerial staff and 1 flight operator) participated in the course. Pre- and post-test evaluations demonstrated significant improvement in knowledge from 53\% (average 10.53, STD 1.6) to $73 \%$ (average 14.53, STD 2.13) $\mathrm{p}$-value $<0.0001)$. Critical deficiencies in information uptake were identified in airway management and flight physiology.

Conclusion: A tailored AMTC may serve as the first step toward the development of a regionally specific aeromedical transport service. Long-term follow-up is needed to evaluate the real impact of this intervention in terms of morbidity and mortality.

Keywords: Rural trauma, Aeromedical transport, Trauma training of nonmedical personnel.

How to cite this article: Aboutanos MB, Mora FE, Nicholson B, Lovelady J, Dhindsa H, Mata LV, Kleiman D, Chin T, King A, Ivatury RR. Trauma Course for an Aerial Medical Transport System in the Amazon Rainforest of Ecuador. Panam J Trauma Critical Care Emerg Surg 2012;1(1):1-5.

Source of support: Nil

Conflict of interest: None declared

\section{RESUMEN}

Objetivos: El transporte aéreo de pacientes heridos en la zona sureste rural Ecuatoriana es proporcionado por las organizaciones humanitarias sin personal médico o de asistencia. Hemos evaluado la viabilidad y utilidad de un curso de transporte aeromédico (TAM) adaptado para el personal no médico (piloto y técnicos) en la selva Ecuatoriana, donde no hay miembros médicos de tripulación formales.

Métodos: Fueron analizados los vuelos aeromédicos en aviones de ala fija en la provincia amazónica de Morona Santiago para delinear los patrones de lesiones $(\mathrm{PL})$ y la razón para el transporte (RPT). Un curso TAM práctico y didáctico de 8 horas fue desarrollado con extensa experiencia en educación y entrenamiento aeromédico por la Universidad del Commonwealth de Virginia (VCU), el Programa Internacional de Desarrollo de Sistemas de Trauma (ITSDP) y Life-Evac de VCU. Se utilizo una evaluación pre-y post test para valorar los antecedentes médicos y la retención de conocimientos de los participantes.

Resultados: Se analizaron 5.716 vuelos aeromédicos en aviones de ala fija entre el mes de enero del 2003 y diciembre del 2005. El curso fue desarrollado sobre la base de 1176 (20\%) RPT como resultado de lesiones traumáticas. La estructura del curso que fue basada en PL identificados incluyo 4 clases didácticas y prácticas en fisiología aérea, manejo de vía aérea, control de sangrado, shock, lesiones musculoesqueléticas, inmovilización y transporte del paciente. 15 estudiantes (4 pilotos, 4 ingenieros, 2 médicos, 4 técnicos aéreos y 1 operador aéreo) participaron en el curso. El pre y post test demostraron una mejora significativa en el conocimiento del $53 \%$ (promedio 10,53, DS 1,6) al 73\% (promedio 14,53, DS 2,13 ) valor $p<0,0001$. Deficiencias críticas en la captación de la información se identificaron en el manejo de vía aérea y la fisiología de vuelo.

Conclusiones: Un curso TAM adaptado puede servir como el primer paso hacia el desarrollo de un servicio de transporte aeromédico específico a nivel regional. Es necesario un seguimiento a largo plazo para evaluar el impacto real de esta intervención en términos de morbilidad y mortalidad.

Palabras clave: Trauma rural, Transporte aeromédico, entrenamiento en trauma del personal no médico.

\section{BACKGROUND}

With more than 5 million deaths every year, violence and injuries account for $9 \%$ of global mortality, as many deaths as from HIV, malaria and tuberculosis combined. Eight of the 15 leading causes of death for people ages 15 to 29 years are injury-related. ${ }^{1-3}$ The America's region account for $11 \%$ of global deaths due to trauma with $90 \%$ of fatalities occurring in low and middle income countries. ${ }^{4,5}$ This is of significance in the Latin American region where injuries and noncommunicable diseases account for greater than $73 \%$ of deaths and $76 \%$ of disability adjusted life years (DALYS). ${ }^{2,6}$ The rural areas shoulder much of the burden of injury where rapid urbanization and development is ongoing without the corresponding improvement in infrastructure and health 
care systems. ${ }^{7,8}$ Trauma care in rural areas of Latin America remains rudimentary without appropriate injury prevention and control efforts. ${ }^{9,10}$

Such statistics are reflected in Ecuador where aggressions (homicides, assaults) and motor vehicle crashes are the leading cause of mortality with an attributable fatality rate of 37.5 per 10,000 inhabitants. ${ }^{11}$ Almost $40 \%$ of Ecuador's population is rural and yet rural trauma remains underestimated and few trauma interventions are targeted to these areas. According to the Ecuadorian Center for National Statistics and Census, , trauma is the second greatest cause of morbidity and the fourth highest cause of mortality. in Southeastern Ecuador. Despite this there is no formal emergency medical system in the region. Some areas are reachable only by air. The aerial transport of injured patients is provided by humanitarian organizations with no medical personnel or assistance. These organizations use fixedwing aircraft that land on dirt air strips in the middle of the jungle. Pretransport care is provided by local community members with minimal medical knowledge who contact the humanitarian organization by radio to evacuate the patient. Patients receive minimal care at the site of injury. Transport is carried out by a pilot with no capability of delivering any time of medical assistance.

The lack of immediate care can contribute significantly to mobility and mortality. Several studies have demonstrated that providing basic trauma care training to local first responders decreases mortality in rural settings. ${ }^{12-15}$ This study evaluated the feasibility and utility of a tailored aeromedical transport (AMT) course for nonmedical personnel (pilot and technicians) in the jungles of Ecuador where there are no formal medical crew members.

\section{METHODS}

Fixed-wing aeromedical flights in the Amazon province of Morona Santiago were analyzed to delineate the injury patterns and reason for transport. An 8-hour didactic and hands-on aeromedical transport course based on injury patterns and reason for transport was developed and administered by the Virginia Commonwealth University (VCU) International Trauma System Development Program (ITSDP) and VCU's aeromedical transport Life Evac. These organizations both have extensive experience in aeromedical education and training in rural and austere settings. Local resources and site of injury were also considered. The lecture topic included basic aerial physiology, airway management, musculoskeletal injury, bleeding and shock. The hands-on skills training included hemorrhage control, dressing, bandaging, musculoskeletal immobilization, splinting and patient transport (Table 1).

\section{Table 1: Lecture and skill sessions}

Lectures:

Aerial physiology

Airway management in remote settings

Musculoskeletal trauma management in the field

Bleeding and shock - the basics of rural management

Skill sessions:

Hemorrhage control, dressing, bandaging

Musculoskeletal immobilization, splinting

Patient transport-from rural to definitive centers

Onsite skill training was carried out in the field and in the rural airport bunker area to optimize training with the local resources present (Fig. 1). Skills training were directed at basic stabilization and rapid transport of the patient to rural or regional hospitals. Basic support and monitoring of the patient was also stressed, as rapid transport is not always feasible in the Amazon areas where weather variability and mechanical failures are common.

An attending physician in trauma/critical care, an emergency medicine physician, and one surgery resident physician as well as three certified aeromedical specialists led the course. Three medical students assisted with logistics and organization. The course took place over a 2 days period.

Participants were selected from the two humanitarian organizations which render aerial emergency transport in the region. Fifteen students participated in the course, including four pilots, four mechanics, two physicians, one flight operator, and one aerial staff member. All students were required to participate in the entire course and evaluation process.

Pre- and post-test course evaluation was used to assess the baseline medical knowledge and information retention of the participants. Each test consisted of 20 multiple choice

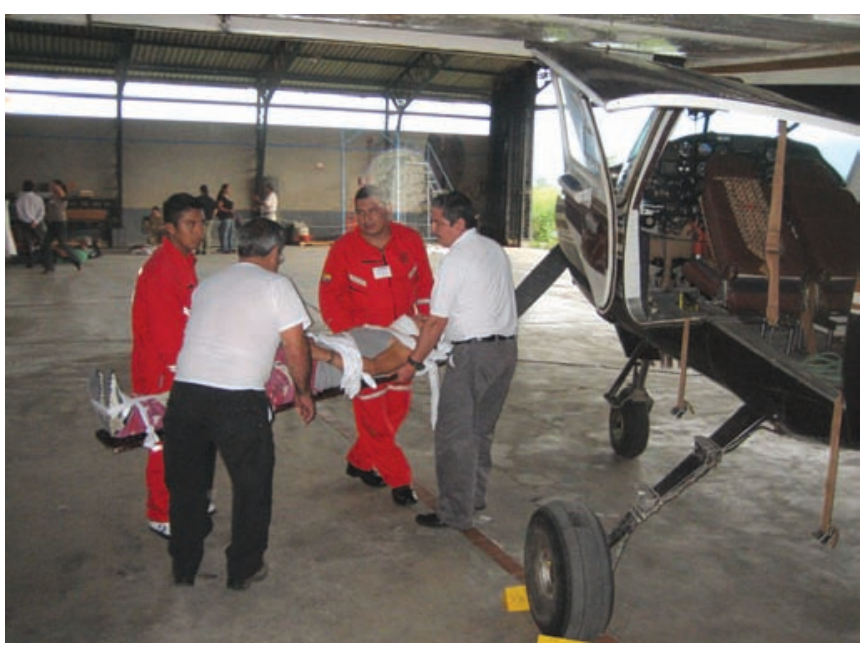

Fig. 1: Onsite training for patient immobilization and transport. Two pilots and 2 technicians transporting patient post-immobilization. The board was designed by the pilots. Torn bed sheets were used for immobilization. Chairs were removed from the aircraft to accommodate the simulated injured patient 
Trauma Course for an Aerial Medical Transport System in the Amazon Rainforest of Ecuador

questions addressing lectures and hands on skills session topics. A paired t-test was used to compare pre- and post-test scores by individual topic. A p-value of less than 0.05 was considered statistically significant.

\section{RESULTS}

5,716 fixed-wing aeromedical transports between Jan 2003 and Dec 2005 were analyzed to determine the injury patterns and the reasons for transport (Table 2). Trauma was the third highest reason for aeromedical transfer. Toxic effect of contact with venomous animals (356 cases, 30\%) was the main reason for transfer of traumatic injuries. Other causes included fractures, burns, and multiple injuries. 50 and $26 \%$ of patients were under the age of 20 and 10 respectively. Flight time averaged between 36 minutes and 6 hours and differed by mechanism and site of injury. There was no traumatic death recorded during transfer. Data on injury severities and outcomes were not available.

\begin{tabular}{lr}
\multicolumn{2}{c}{ Table 2: Aeromedical transport } \\
\hline Aeromedical transport & $\mathrm{N}=5716$ \\
Age (years) & 20 \\
Sex (M/F) & $2 / 1$ \\
Reason for transfer & $n(\%)$ \\
Infectious disease & $1341(23)$ \\
Respiratory disease & $1229(21)$ \\
Injury & $1176(20)$ \\
Endocrine/nutrition & $737(13)$ \\
Ob-gyn & $574(10)$ \\
Gastrointestinal & $513(9)$ \\
Genitourinary & $444(8)$ \\
Injury type FT avg./range (min) & \\
Head and neck & $101 / 48-360$ \\
Trunk & $111 / 48-360$ \\
Upper extremity & $72 / 36-270$ \\
Lower extremity & $68 / 36-120$
\end{tabular}

The basic trauma course was developed between 2006 and 2007 based on the above injury patterns and local realities of transport time. The course was administered in 2008.

The 15 student participants included four pilots, four engineers, two physicians, four aerial staff and one flight operator. Pre- and post-test evaluations demonstrated significant overall improvement in knowledge from 53\% [average 10.53 , STD 1.6) to $73 \%$ (average 14.53 , STD 2.13) p-value $<0.0001$ ] (Table 3). Comparing pre-test and post-test scores, improvement was noted in all the sessions taught with noted significant improvement on the topic of hemorrhage control ( 34 to $77 \%$, p-values $<0.0001$ ). Critical deficiencies in information uptake were identified in airway management.

\begin{tabular}{llllr}
\multicolumn{5}{c}{ Table 3: Course evaluation-pre vs post } \\
\cline { 2 - 5 } Subject & $\begin{array}{l}\text { Total } \\
\text { questions }\end{array}$ & $\begin{array}{c}\text { Pre- } \\
\text { test }\end{array}$ & $\begin{array}{c}\text { Post- } \\
\text { test }\end{array}$ & p-value \\
\cline { 2 - 5 } & \multicolumn{4}{c}{ Correct (\%) } \\
$\begin{array}{llllr}\text { Aerial physiology } \\
\text { Hemorrhage }\end{array}$ & 165 & 66.1 & 75.8 & 0.0688 \\
$\begin{array}{l}\text { Control } \\
\text { Airway }\end{array}$ & 90 & 34.4 & 76.7 & $<0.0001$ \\
management & 30 & 36.7 & 46.7 & 0.6010 \\
$\begin{array}{l}\text { Patient transport } \\
\text { Total }\end{array}$ & 15 & 46.7 & 66.7 & 0.4621 \\
& 300 & 52.7 & 72.7 & $<0.0001$
\end{tabular}

\section{DISCUSSION}

The development of this course was especially challenging due to our intention of training nonmedical personnel to provide basic trauma care in a very limited setting. The diversity of the participants was such that there was no consistent baseline level of medical knowledge. The course was tailored to the main types of injuries seen in the region with the aim of achieving basic stabilization of patients to ensure safe transfer to local hospitals where medical personnel is available.

Significant emphasis was put on aerial physiology to minimize any additional harm that can be incurred on the patient. This was reflected also by the number of test questions that were posed to ensure knowledge acquisition of basic concepts in aerial physiology. The course did not attempt to be comprehensive. It mainly stressed the minimum required to identify a serious injury, stabilize the patient, and provide rapid transport. The duration of the course was two days which was consistent with other suggested studies on the time needed for basic prehospital training of nonmedical personnel. ${ }^{16,17}$

Although the results of the post-test scores are encouraging in terms of improving the medical knowledge of aerial EMS providers, the long-term retention, or the change in outcome of the transported patients was not tested. Previous studies have demonstrated that providing basic trauma care training to local first responders decreases mortality in rural settings. ${ }^{12-15} \mathrm{~A}$ recent evaluation carried out by Kappel et al to evaluate the impact of the American College of Surgery's Rural Trauma Team Development Course (RTTDC) in Western Virginia noted a significant reduction in delays in the transport process of the rural trauma patient. ${ }^{18}$ The study was based on the analysis of the process of care and outcome from the West Virginia State trauma registry. A regional trauma registry is currently being instituted in Southeastern Ecuador by ITSDP to evaluate the outcomes and any improvement in appropriateness of patient transport and patient transport time. 
Additionally, no formal objective structured clinical examination (OSCE) was carried out. We believe this was a deficiency in our course. The addition of OSCE to the multiple choice questions (MCQ) format has been effectively used to test students and evaluate the improvement in the postcourse period, and to assess clinical performance. ${ }^{19-22}$ We have also used OSCE evaluations in our basic trauma Course (BTC) administered to rural physicians and noted significant deficiencies that otherwise would have not been revealed with the MCQ alone. Due to time constraint, and to avoid any perceived intimidation for the nonmedical personnel, we were reluctant to administer OSCE in this first aeromedical course. It will be considered in subsequent course administrations and evaluations.

As expected from the type of students selected to participate in the course the highest pretest scores were in aerial physiology as compared to clinical management and transport of the patient. Although improvement was noted in all of the systems, it was concerning that only minimal improvement was noted in the airway management.

Upon further evaluation and review of the test scores with the students, a misunderstanding of the physiological definition and use of the word 'airway' was identified which differ significantly from the 'pilot' understanding of the word airway as it applies to flight management. Such nuances in the development and administration of a rural course to nonmedical personnel are not uncommon. It also highlights the importance of using the test itself as an important tool for education which was carried out in our course.

Finally we believe that training nonmedical personnel in silo may not be effective. Complimentary courses to other health care providers involved in the care of the injured patient are necessary. While this aeromedical course was administered, three additional simultaneous courses were administered to the nurses (basic rural nursing course), the rural physicians (BTC), and the prehospital providers (basic paramedic course). This was logistically challenging. The integration of these courses was carried out to a limited extent. The impact is currently being evaluated. It may prove to be an important step for development of rural trauma systems in the region.

\section{CONCLUSION}

A tailored AMTC is the first step toward the development of a regionally specific aeromedical transport service. Longterm monitoring and evaluation are needed to evaluate the real impact of this intervention in terms of reduced morbidity and mortality.

\section{REFERENCES}

1. Hofman K, Primack A, Keusch G, et al. Addressing the growing burden of trauma and injury in low- and middle-income countries. Am J Public Health 2005;95(1):13-17.

2. Murray CJ, Lopez AD. The global burden of disease: A comprehensive assessment of mortality and disability from diseases, injuries, and risk factors in 1990 and projected to 2020. Cambridge, Mass: Harvard University Press 1996.

3. Murray CJL, Lopez AD. Global health statistics: A compendium of incidence prevalence and mortality estimates for over 200 conditions. Cambridge, Mass: Harvard University Press 1996.

4. Pan American Health Organization. Regional core health data and country profile initiative. 2005-2005 www.paho.org accessed Nov 10, 2010

5. World Health Organization. The world health report: Changing history. Geneva, Switzerland 2004.

6. Perel P, Cases JP, Ortiz Z, et al. Noncommunicable diseases and injuries in Latin America and the Caribbean: Time for action. PLoS Medicine 2006;3(9):e344, 1448-51.

7. Fraser B. Traffic accidents scar Latin America's roads. Lancet 2005;366(9487):703-04.

8. Tercero F, Andersson R, Pena R, et al. The epidemiology of moderate and severe injuries in a Nicaraguan community: A household-based survey. Public Health 2006;120(2):106-14.

9. Richman $\mathrm{M}$, Shayne $\mathrm{P}$, Heron $\mathrm{S}$, et al. Injury control in Honduras: A survey of injury mortality. Ann Emerg Med 2000;36(4):333-39

10. Aboutanos MB, Rodas EB, Aboutanos SZ, et al. Trauma education and care in the jungle of Ecuador, where there is no advanced trauma life support. J Trauma 2007;62(3):714-19.

11. Instituto Nacional de Estadisticas y Censos del Ecuador- 2010.

12. Husum H, Gilbert M, Wisborg T. Med Teach. Training prehospital trauma care in low-income countries: The 'Village University’ experience 2003 Mar;25(2):142-48.

13. Mock C. Improving prehospital trauma care in rural areas of low-income countries. J Trauma 2003 Jun;54(6):1197-98.

14. Husum H, Gilbert M, Wisborg T, Van Heng Y, Murad M. Rural prehospital trauma systems improve trauma outcome in lowincome countries: A prospective study from North Iraq and Cambodia. J Trauma 2003 Jun;54(6):1197-98.

15. Van Heng Y, Davoung C, Husum H. Non-doctors as trauma surgeons? A controlled study of trauma training for nongraduate surgeons in rural Cambodia. Prehosp Disaster Med 2008 NovDec;23(6):483-99; discussion 490-91.

16. Champion HR, Copes WS, Sacco WJ, Lawnick MM, Keast SL, Bain LW Jr, et al. The major trauma outcome study: Establishing national norms for trauma care. Journal of Trauma 1990;30: 1356-65.

17. Nafissi N, Saghafinia M., Balochi K. Improving trauma care in rural Iran by training existing treatment chains. Rural and Remote Health 2008;8:881 (Online). Available from: http:// www.rrh.org.au. Accessed Nov 10, 2010 .

18. Kappel DA, Rossi DC, Polack EP, Avtgis TA, Martin MM. Does the rural trauma team development course shorten the interval from trauma patient arrival to decision to transfer? J Trauma. 2011 Feb;70(2):315-19.

19. Ali J, Cohen R, Adam R, Gana T, et al. Teaching effectiveness of the ATLS program as demonstrated by an OSCE for practicing Physicians. World J Surg 1996:20;1121-26. 
20. Harden R, Gleeson F. Assessment of clinical competence using an objective structured clinical examination. Med Ed 1979:13;41.

21. Ali J, Cohen R, Reznick R. Demonstration of acquisition of trauma management skills by Senior Medical Students Completing the ATLS Program. J of Trauma 1995;38(5):687-91.

22. Tracey J, Rodwell P, Clearwater G. Development and evaluation of the rural trauma and emergency care roadshow. NZ Med J 1999;112:144-47.

\section{ABOUT THE AUTHORS}

\section{Michel B Aboutanos (Corresponding Author)}

International Trauma System Development Program, Virginia Commonwealth University, Richmond, Virginia; Division of Trauma, Department of Surgery, Virginia Commonwealth University, Richmond, Virginia, USA, e-mail: mbaboutanos@mcvh-vcu.edu

\section{Francisco E Mora}

International Trauma System Development Program, Virginia Commonwealth University, Richmond, Virginia, USA, Department of Surgery, University of Arizona, Tucson, Arizona, USA

\section{Benjamin Nicholson}

International Trauma System Development Program, Virginia Commonwealth University, Richmond, Virginia; Life Evac, Virginia Commonwealth University, Richmond, Virginia; Department of Emergency Medicine, Virginia Commonwealth University, Richmond Virginia, USA

\section{Jay Lovelady}

International Trauma System Development Program, Virginia Commonwealth University, Richmond, Virginia; Life Evac, Virginia Commonwealth University, Richmond, Virginia; Department of Emergency Medicine, Virginia Commonwealth University, Richmond Virginia, USA

\section{Harrinder Dhindsa}

International Trauma System Development Program, Virginia Commonwealth University, Richmond, Virginia; Life Evac, Virginia Commonwealth University, Richmond, Virginia; Department of Emergency Medicine, Virginia Commonwealth University, Richmond Virginia, USA

\section{Lina V Mata}

International Trauma System Development Program, Virginia Commonwealth University, Richmond, Virginia; Division of Trauma, Department of Surgery, Virginia Commonwealth University Richmond, Virginia, USA

\section{Debbie Kleiman}

International Trauma System Development Program, Virginia Commonwealth University, Richmond, Virginia; Department of Emergency Medicine, Virginia Commonwealth University, Richmond Virginia, USA

\section{Theresa Chin}

International Trauma System Development Program, Virginia Commonwealth University, Richmond, Virginia; Department of Surgery, University of Colorado, Denver, Colorado, USA

\section{Ashley King}

International Trauma System Development Program, Virginia Commonwealth University, Richmond, Virginia; Division of Urology, Department of Surgery, Virginia Commonwealth University Richmond, Virginia, USA

\section{Rao R Ivatury}

International Trauma System Development Program, Virginia Commonwealth University, Richmond, Virginia; Division of Trauma, Department of Surgery, Virginia Commonwealth University Richmond, Virginia, USA 